\title{
Micro-damage of Tungsten Fiber Reinforced Copper Matrix Composites under Hypervelocity Impact
}

\author{
Zhang Yang, Wu Zhe
}

Northeast Forestry University, Harbin 150040, China

\begin{abstract}
Wf} / \mathrm{Cu}_{78} \mathrm{Al}_{10} \mathrm{Fe}_{6} \mathrm{Ni}_{6}$ composite was fabricated from $\mathrm{Cu}_{78} \mathrm{Al}_{10} \mathrm{Fe}_{6} \mathrm{Ni}_{6}$ alloy and tungsten fiber by infiltration casting. $\mathrm{Wf} / \mathrm{Cu}_{78} \mathrm{Al}_{10} \mathrm{Fe}_{6} \mathrm{Ni}_{6}$ composite hypervelocity projectile impacted concrete target at the speed of $2.4 \mathrm{~km} / \mathrm{s}$ by a two-stage light gas gun. Microstructure of the residual projectiles after penetration was observed with transmission electron microscope (TEM). Results show that due the effect of high temperature and pressure during the process of penetration, there are different microstructures in different zones of the residual projectiles, i.e. amorphous microstructures, recrystallization microstructures, twins, and dislocations in the order from warhead to afterbody. Matrix copper alloy melts and then rapidly solidifies owing to high temperature produced by projectiles during the process of impact, and thus amorphous microstructures are generated. Recrystallization microstructures are generated because of rotational dynamic recrystallization of copper matrix. Twins and high-density dislocations are generated due to serious plastic deformation of projectiles under large dynamic loads in the process of penetration.
\end{abstract}

Key words: composites; microstructure; hypervelocity impact

Among current researches on projectiles into concrete targets, penetration velocity was mostly less than $1 \mathrm{~km} / \mathrm{s}$, which was low, and at the same time high-strength steels and tungsten alloys were mostly adopted as projectile materials. With the development of kinetic energy projectiles to high speed, high strength and high density, the demand to mechanical properties of materials used for armor-piercing projectiles increases higher and higher, and the traditional high-strength steels and tungsten alloys become increasingly unsuited to the military requirements ${ }^{[1-4]}$. Composites are composed of two or more kinds of materials reasonably, so they often possess better performance than a single material. Therefore, many countries start to do research in composites' projectile in recent years ${ }^{[5-7]}$. Tungsten fibers, which possess the advantages of high density and high melting point, were formed by drawing the massive tungsten at high temperature ${ }^{[8-13]}$. Preliminary studies demonstrated that $\mathrm{Wf} / \mathrm{Cu}_{78} \mathrm{Al}_{10} \mathrm{Fe}_{6} \mathrm{Ni}_{6}$ composite had excellent dynamic mechanical properties and could be used as an alternative material to hypervelocity kinetic energy projectiles. However, there are few researches on the composite's hypervelocity impact and the researches on its damage behavior and organizational change have hot been carried out yet.

To this end, this paper adopted a two-stage light gas gun to carry out the test of $\mathrm{Wf} / \mathrm{Cu}_{78} \mathrm{Al}_{10} \mathrm{Fe}_{6} \mathrm{Ni}_{6}$ composite hypervelocity (with the speed of $2.4 \mathrm{~km} / \mathrm{s}$ ) projectile into concrete target and TEM was used to study changes in the projectile microstructures after hypervelocity penetration, which laid the foundation for the application of $\mathrm{Wf} / \mathrm{Cu}_{78} \mathrm{Al}_{10} \mathrm{Fe}_{6} \mathrm{Ni}_{6}$ composite in hypervelocity kinetic energy projectiles.

\section{Experiment}

In the test, $\mathrm{Wf} / \mathrm{Cu}_{78} \mathrm{Al}_{10} \mathrm{Fe}_{6} \mathrm{Ni}_{6}$ composite was chosen as the material of experimental projectiles. Wf $/ \mathrm{Cu}_{78} \mathrm{Al}_{10} \mathrm{Fe}_{6} \mathrm{Ni}_{6}$ alloy was chosen as the matrix, and $0.1 \mathrm{~mm}$ diameter straightening tungsten fibers were chosen as the reinforcement in the $\mathrm{Wf} / \mathrm{Cu}_{78} \mathrm{Al}_{10} \mathrm{Fe}_{6} \mathrm{Ni}_{6}$ composites.

Received date: October 25, 2015

Foundation item: The Fundamental Research Funds for the Central Universities (2572015CB10, 2572015BB09); Natural Science Foundation Project of Heilongjiang Province (C201413); National Natural Science Foundation of China (31200434); China Postdoctoral Science Foundation (2013M531007)

Corresponding author: Wu Zhe, Ph. D., College of Mechanical and Electrical Engineering, Northeast Forestry University, Harbin 150040, P. R. China, Tel: 0086-451-82190397, E-mail: 13136661358@163.com 
$\mathrm{Wf} / \mathrm{Cu}_{78} \mathrm{Al}_{10} \mathrm{Fe}_{6} \mathrm{Ni}_{6}$ composites were prepared by infiltration casting. The material density was $15.9 \mathrm{~g} / \mathrm{cm}^{3}$ by testing.

In order to better observe the changes in projectile microstructures after penetration, the test adopted a large-size projectile. The projectile was a flat-nosed one with the diameter of $12 \mathrm{~mm}$ and the draw ratio of 10:1. Tungsten fibers of $0.1 \mathrm{~mm}$ arranged vertically along axis in the projectile core, the outer of which was also wound by tungsten fibers of $0.1 \mathrm{~mm}$. The thickness of the winding layer was $2.5 \mathrm{~mm}$. Fig. 1 is SEM image of the composites. The size of the concrete target was $\Phi 1000 \mathrm{~mm} \times 1000 \mathrm{~mm}$. Six standard test blocks with dimensions of $70.7 \mathrm{~mm} \times 70.7$ $\mathrm{mm} \times 70.7 \mathrm{~mm}$ should be cast for the static mechanical property test while the concrete was casting. The target parameters obtained after test were as follows: density of $2.5 \mathrm{~g} / \mathrm{cm}^{3}$ and the compressive strength of $44 \mathrm{MPa}$. The hypervelocity impact test was completed on the two-stage light gas gun and $2.4 \mathrm{~km} / \mathrm{s}$ should be selected as the initial velocity of penetration. In the process of penetration, due to the error of charge amount of the light gas gun, the actual velocity error was within $0.1 \mathrm{~km} / \mathrm{s}$, which had little effect on the results of penetration. Normal penetration was chosen as the penetration method, i.e. during the impact, the projectile and the concrete target formed a $90^{\circ}$ angle. After the penetration, microstructures of the residual projectiles were observed by TEM.

\section{Results and Discussion}

After the penetration, the concrete target was destroyed to get the residual projectile. The residual length of the projectile is $18 \mathrm{~mm}$, as shown in Fig.2a. The projectile was cut along the axis. As shown in Fig.2b, the area between Line $\mathrm{M}$ and Line $\mathrm{N}$ in the cross section was observed with a transmission electron microscope (TEM). The area between Line $\mathrm{M}$ and Line $\mathrm{N}$ was cut off in the cross section with the wire cutting machine from the projectile with the thickness of $1 \mathrm{~mm}$. The wire cutting machine was used to divide this area into small blocks with the length of $1 \mathrm{~mm}$ along the axial

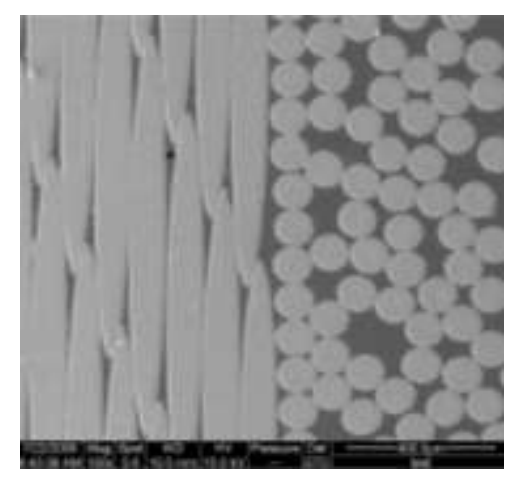

Fig.1 SEM image of $\mathrm{W}_{\mathrm{f}} / \mathrm{Cu}_{78} \mathrm{Al}_{10} \mathrm{Fe}_{6} \mathrm{Ni}_{6}$ composites at axial direction used in the experiment
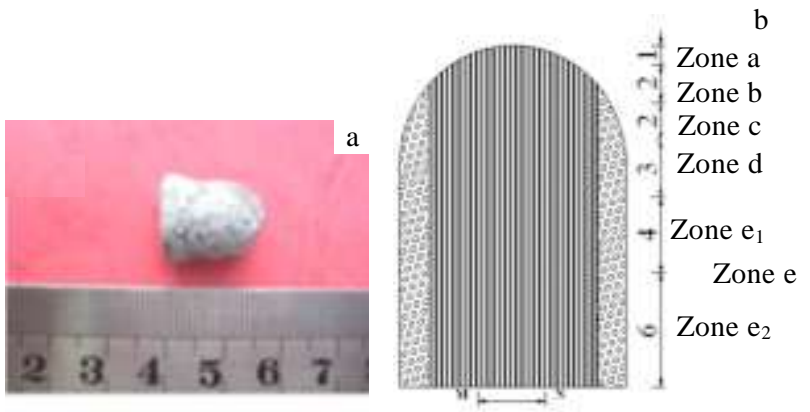

Fig.2 Residual projectile: (a) macro-morphology of the residual projectile and (b) schematic diagram of microstructural distribution in the residual projectile

direction, i.e. along the direction tungsten fibers arranged vertically, and the small blocks were numbered. The samples were worked into TEM samples by the sandpaper and the ion polishing machine and these samples were observed by the TEM. The observed cross section were divided into 5 areas according to changes in microstructures of each sample. As shown in Fig. 2b, the 5 areas are Zone a, b, c, d, and e, which are the amorphous microstructure area, the dynamic recrystallization area, the twins area, the twins and dislocation area and the dislocation area, respectively.

\subsection{Amorphous}

Zone a, at the forefront of warhead, was worst impacted when the hypervelocity projectile penetrated into concrete target. As shown in Zone A in Fig.3a, after series of tilting, the structures remained unchanged. The diffraction analysis results are shown in Fig.3b. Halo shaped diffraction pattern is the typical characteristic of the amorphous structures. Fig.3c shows the corresponding EDX spectrum of Zone a, indicating that major components of the zone are $\mathrm{Cu}, \mathrm{Al}, \mathrm{Fe}$ and $\mathrm{Ni}$ as well as a small amount of $\mathrm{W}$ diffusing into the zone. Zone $\mathrm{B}$ close to tungsten fibers-juncture of the matrix alloy and tungsten fiber interface was characterized by diffraction analysis, as shown in Fig.4b, The diffraction pattern of Zone B is also halo shaped, the same as Zone A, indicating that Zone $\mathrm{B}$ is also an amorphous structure region. However, it is different from the diffraction of Zone A that there are crystal spots in the diffraction of Zone B, indicating that there are crystals in Zone B. As could be observed from the high resolution phase, there are nanometer crystals of $\mathrm{Cu}$ existing in this zone, as indicated by the arrow in Fig.4a. Nanometer crystals are formed after $\mathrm{Cu}$ matrix is subjected to dynamic recrystallization. However, from the diffraction image and the high resolution phase, as shown in Fig.4b, there are few nanometer crystals in Zone a. Through observation of microstructures in Zone a, Zone a is dominated by amorphous structures of $\mathrm{Cu}$. 

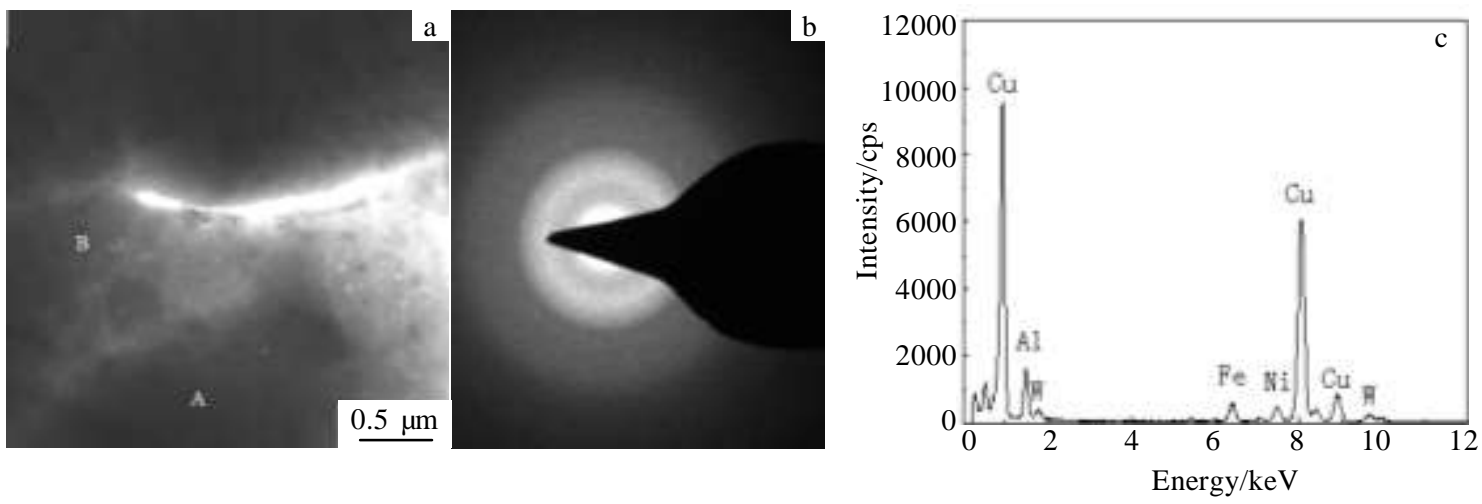

Fig.3 TEM observation of amorphous microstructure formed in $\mathrm{Cu}$ alloy matrix: (a) amorphous microstructure, (b) SADP of Zone A, and (c) EDX spectrum of Zone A

Studies has shown that the formation of amorphous structures included the following three forms ${ }^{[14-16]}$ : (a) rapid solidification amorphization-disordered materials at high temperature didn't have enough time to crystallize but form amorphous structures in the process of rapid solidification, such as fuse quenching and sputtering; (b) solid state amorphization reaction-the amorphous phase was formed by diffusion of atoms in the process of severe plastic deformation and amorphization from solid state reaction, such as mechanical alloying; (c) high-pressure-induced amorphous-solid materials under high pressure were converted to the amorphous state by a series of processing. In the test of this paper, the projectile penetrated into concrete target at the speed of $2.4 \mathrm{~km} / \mathrm{s}$. At the moment when the projectile contacted the target and in the process of penetration, the warhead had been under high temperature and pressure ${ }^{[17]}$. Through observation of the warhead under high-velocity penetration, it could be found that there are a large number of molten matrix copper alloys in the warhead, indicating that the temperature rise is caused by the impact and the plastic deformation is sufficient to make matrix copper alloys existing in the warhead melt or vaporize. Matrix copper alloys existing in the warhead melts and then rapidly solidifies due to inability to withstand serious plastic deformation and high pressure, and thus the amorphous structures in the warhead are generated.

\subsection{Dynamic recrystallization}

As shown in Fig.5a, matrix copper alloy in Zone b could be observed, and there are a large number of tiny nanocrystals with diameters ranging from $20 \sim 50 \mathrm{~nm}$. In Fig. $5 b$, the diffraction image of this zone, the diffraction spots of the zone are formed by continuous diffraction rings. By the calibration, crystal particles in the zone are nanometer crystals of $\mathrm{Cu}$, indicating dynamic recrystallization of copper in this zone. Though there are nanometer crystals of $\mathrm{Cu}$ in Zone a, the number is small. While in most regions

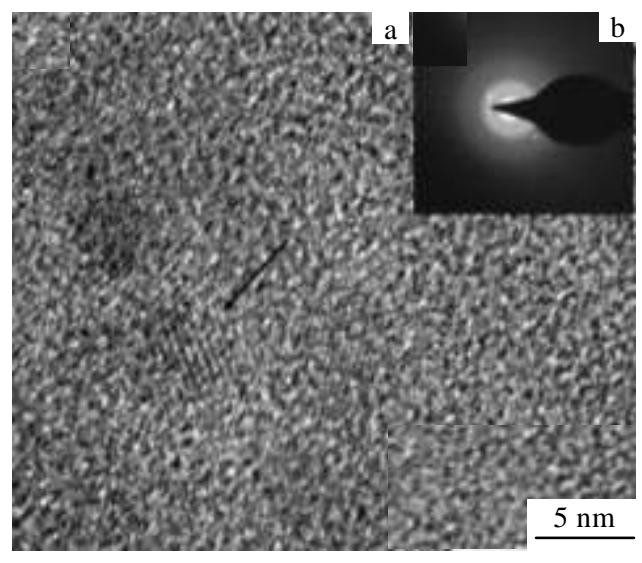

Fig.4 (a) HREM morphology of nanocrystalline in $\mathrm{Cu}$ alloy matrix and (b) SADP of nanocrystalline

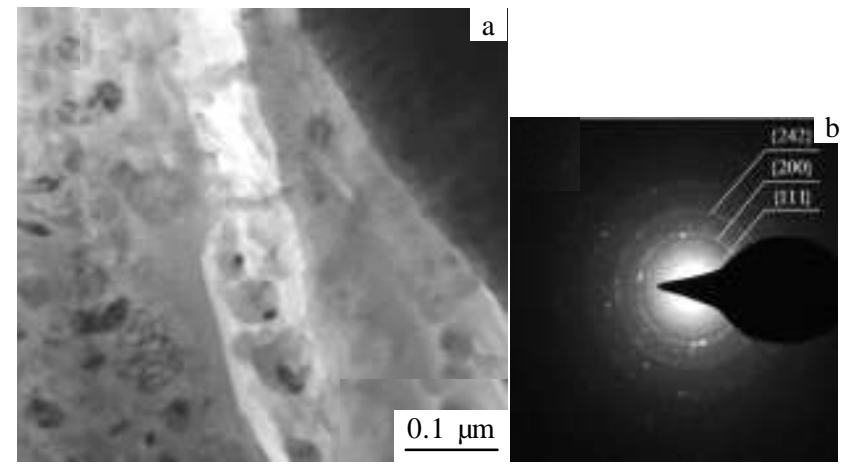

Fig.5 TEM observation of recrystallization formed in $\mathrm{Cu}$ matrix: (a) recrystallized grains and (b) SADP of recrystallization

of Zone b, a number of nanometer crystals formed by dynamic recrystallization of copper could be found, so Zone $\mathrm{b}$ is defined as a dynamic recrystallization zone. In the process of $\mathrm{W}_{\mathrm{f}} / \mathrm{Cu}_{78} \mathrm{Al}_{10} \mathrm{Fe}_{6} \mathrm{Ni}_{6}$ composite projectile into concrete target at hypervelocity, the projectile seriously 
impacts the target while the target strongly impacts the projectile, so that the warhead is subjected to serious plastic deformation, which makes materials in the warhead meet the energy requirements of recrystallization. Moreover, in the process of impact, high adiabatic temperature rise in the warhead makes materials here meet the temperature requirements of recrystallization ${ }^{[18]}$. The above two factors together ultimately leads to the dynamic recrystallization of copper matrix in the warhead ${ }^{[19,20]}$.

\subsection{Twins}

As shown in Fig.6a, matrix alloy in Zone c could be observed, Zone c is dominated by deformed twin crystal structures. In general, close-packed hexagonal metal with low symmetry structure and few slip systems is easy to generate twinning deformation. Body centered cubic metal only generates deformation at room temperature and under impact loading, but when the critical shear stress of slip is significantly improved, the general deformation rate will also generate twinning. For the face-centered cubic metal, because of its high symmetry structure, more slip systems and easy occurrence of slip, twinning is generally difficult to occur, but in exceptional circumstances, face-centered cubic metal can also produce twinning phenomena. For example, under conditions of explosion and high-speed impact, twins would occur before the dislocation slip could proceed $^{[21,22]}$. The generation of twins has a great relationship with the stacking fault energy. The higher the stacking fault energy is, the more difficult the formation of twins is. For instance, $\mathrm{Ni}, \mathrm{Al}$ and $\mathrm{Cu}$ have very high stacking fault energy (stacking fault energy of Ni about 400 $\mathrm{MJ} / \mathrm{m}^{2}$, stacking fault energy of $\mathrm{Al}$ about $200 \mathrm{MJ} / \mathrm{m}^{2}$, and stacking fault energy of $\mathrm{Cu}$ about $73 \mathrm{MJ} / \mathrm{m}^{2}$ ), so twinning is difficult to occur. However, adding alloying elements would significantly reduce metal stacking fault energy, resulting in stacking faults. For example, a lot of stacking faults could be found in the deformed structures of $\alpha$ brass. According to Schneider's research ${ }^{[23]}$, adding $2 \%$ of Al to copper would reduce the stacking fault energy of copper alloy to $37 \mathrm{MJ} / \mathrm{m}^{2}$. The matrix copper alloy used in this experiment contained $10 \%$ of $\mathrm{Al}$ and the existence of $\mathrm{Al}$ would greatly reduce matrix stacking fault energy ${ }^{[24]}$. In this way, when $\mathrm{W}_{\mathrm{f}} / \mathrm{Cu}_{78} \mathrm{Al}_{10} \mathrm{Fe}_{6} \mathrm{Ni}_{6}$ composite material is subjected to impact, there will be a lot of deformation twins in the matrix copper alloy.

As shown in Fig.6a, the density of deformed twins is very high and there is overlapping of twins in some zones. Inside the deformed twins there are high-density dislocations which multiply and glide inside the twins and accumulate on the twin boundaries. Meanwhile, as shown in Fig.6b, there are obvious dislocation walls formed between the twin boundaries. Through researches on recrystallized microstructure formation mechanism in Zone b, high-density dislocations of deformed twins and inside the twins are the main reason for recrystallization of copper. Though there are deformed twins and high-density dislocations in Zone c, copper matrix recrystallization does not occur, the reason for which is that the copper is relatively farther from the warhead and the temperature and energy requirements of copper recrystallization are insufficient.

\subsection{Twins and dislocation}

Fig.7 shows matrix copper alloy in Zone d. Zone $d$ is dominated by high-density twins and dislocations. As shown in Fig.7a and 7b, the density of twins and dislocations in areas near the warhead in Zone $d$ is higher. As shown in Fig.7c and 7d, the density of twins and dislocations in areas for away from the warhead in Zone $d$ was lower. As could be seen from Fig.7a, 7b, 7c and 7d, there were high-density dislocations existing between twins.

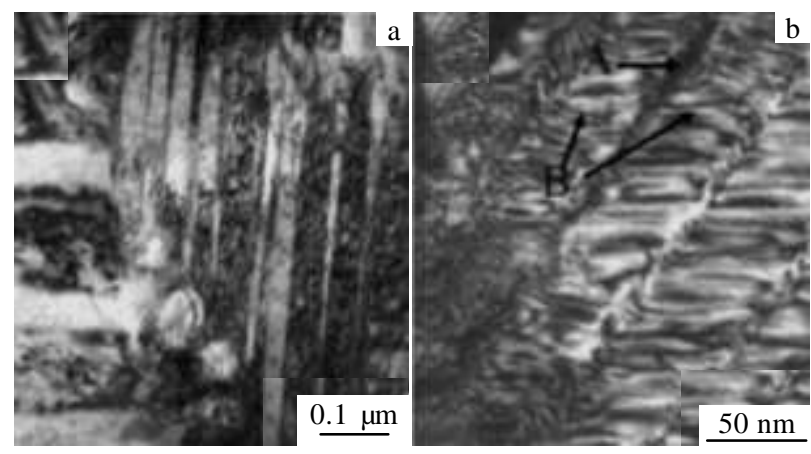

Fig.6 Twins in the $\mathrm{Cu}$ matrix of $\mathrm{Wf} / \mathrm{Cu}_{78} \mathrm{Al}_{10} \mathrm{Fe}_{6} \mathrm{Ni}_{6}$ composites: (a) the crossing of twins and (b) dislocations in twins

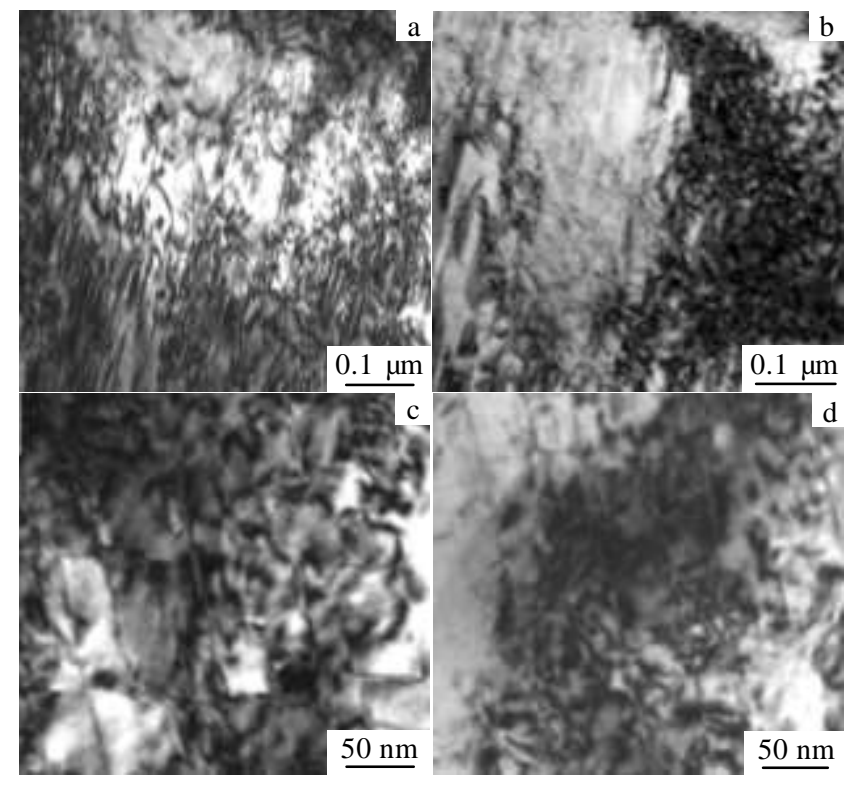

Fig.7 Twins and dislocation in the matrix of $\mathrm{Wf} / \mathrm{Cu}_{78} \mathrm{Al}_{10} \mathrm{Fe}_{6} \mathrm{Ni}_{6}$ composites: (a, b) high density twins and (c, d) low density twins 
Zone $\mathrm{d}$ was a transitional area of twins to dislocations.

\subsection{Dislocation}

As show in Fig.8, structures in Zone e are mainly high-density dislocations, indicating that this zone is also subjected to impact; twins are rare in this zone, indicating that the impact and deformation are small. According to dislocation density degree, Zone $\mathrm{e}$ is divided into two regions $\mathrm{e}_{1}$ and $\mathrm{e}_{2}$. Fig.8a shows that dislocation density in $\mathrm{e}_{1}$ area is very high and serious piling up of dislocations appears. Also, there are cellular dislocations in some areas of $\mathrm{e}_{1}$ area, as indicated by the arrows in Fig. $8 \mathrm{~b}$. Under dynamic impact, the area having more dislocation cells is more likely to be subjected to dynamic recrystallization of copper. Though there are dislocation cells in $\mathrm{e}_{1}$ area, recrystallized grain and sub-grain boundary are not observed, indicating that there are a lot of dislocation cells in this area, but conditions for the occurrence of dynamic recrystallization are insufficient. The analysis suggests that the nonoccurrence of copper matrix recrystallization is attributed to temperature in this area not reaching the temperature spot of recrystallization. The test of projectile into concrete target was carried out at room temperature. Because $e_{1}$ area is far from the forefront of the impact, the impact and deformation are small, and the temperature rise is not sufficient to generate dynamic recrystallization of copper matrix.

In Fig.9, matrix alloy in $\mathrm{e}_{2}$ area could be observed. The structures in the projectile afterbody are mainly dislocations, most of which are linear dislocations. Dislocation network could be found in Fig.9. Although the dislocation density in $\mathrm{e}_{2}$ area is significantly lower than that in $\mathrm{e}_{1}$ area, the dislocation density is still higher than that before the projectile into concrete target. There are two possible reasons for a certain density of dislocations in $e_{2}$ area. One is that the projectile afterbody is subjected to some impact in the process of penetration, while the other is that the sabot strongly impacts the projectile afterbody when the projectile is launched. The superposition of these two factors will result in rise in dislocation density of the projectile afterbody.

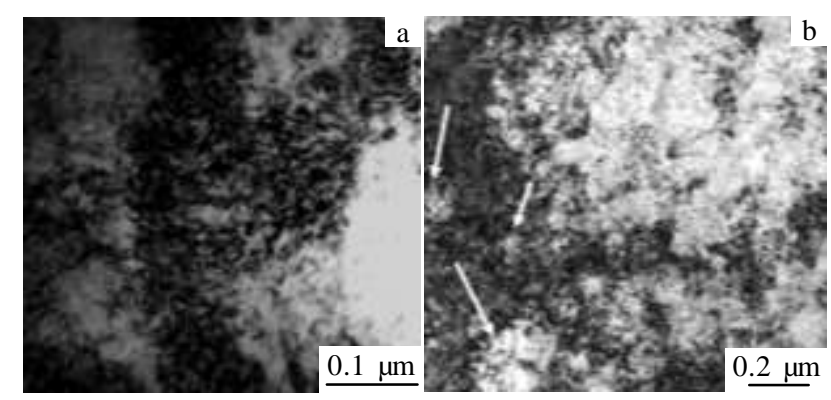

Fig.8 Dislocations in the matrix of $\mathrm{Wf} / \mathrm{Cu}_{78} \mathrm{Al}_{10} \mathrm{Fe}_{6} \mathrm{Ni}_{6}$ composites: (a) dislocation pile-up and (b) dislocation cells

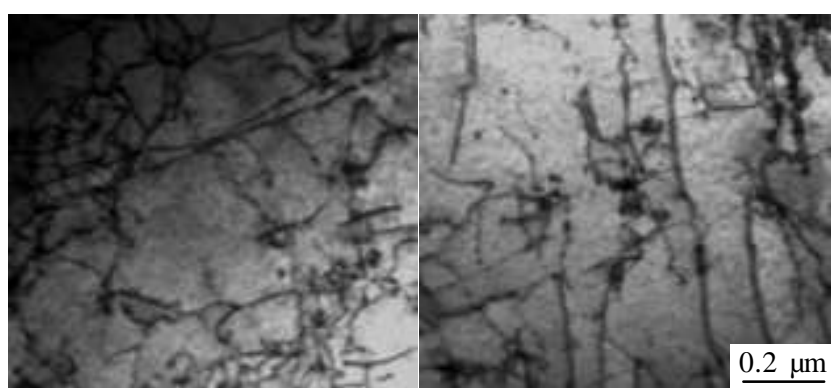

Fig.9 Dislocation network in the matrix of $\mathrm{Wf} / \mathrm{Cu}_{78} \mathrm{Al}_{10} \mathrm{Fe}_{6} \mathrm{Ni}_{6}$ composites

\section{Conclusions}

1) After penetration there are amorphous microstructures, recrystallization microstructures, twins, and dislocations in the matrix alloy of $\mathrm{W}_{\mathrm{f}} / \mathrm{Cu}_{78} \mathrm{Al}_{10} \mathrm{Fe}_{6} \mathrm{Ni}_{6}$ composite.

2) The diversity of microstructures is mainly caused by high temperature and pressure generated under the condition of hypervelocity impact. Amorphous microstructures are generated due to melting and rapid solidification of matrix copper alloy in the process of projectile impact.

3) Recrystallization microstructures are generated due to rotational dynamic recrystallization of copper matrix. Twins and high-density dislocations appear due to serious plastic deformation of projectiles under large dynamic loads in the process of penetration.

\section{References}

1 Zou D L, Zhen L, Zhu Y et al. Material Design[J], 2010, 31(8): 1707

2 Randrianarivony F M, Lair S, Quinones S A et al. Journal of Materials Science [J], 2002, 37(24): 5197

3 Liu J X, Li S K, Fan A L et al. Materials Science and Engineering $A[\mathrm{~J}], 2008,487(1-2): 235$

4 Khalid F A, Bhatti M R. Journal Materials Engineering and Performance [J], 1999, 8(1): 46

5 Conner R D, Dandliker R B, Johnson W L. Acta Materials[J], 1998, 17(17): 6089

6 Zhang H F, Li H, Wang A M et al. Intermetallics[J], 2009, 17(12): 1070

7 Kim H G, Kim K T. International Journal of Mechanical Sciences [J], 2000, 42(7): 1339

8 Manel R R, Jan O. Engineering Fracture Mechanics[J], 2009, 76(10): 1485

9 Schade P. International Journal of Refractory Metals \& Hard Materials[J], 2000, 8(6): 648

10 Schade P. International Journal of Refractory Metals \& Hard Materials[J], 2006, 24(4): 332

11 Ma W F, Kou H C, Chen C S et al. Materials Science and Engineering $A[\mathrm{~J}], 2008,486(1-2): 308$ 
12 Qiu K Q, Wang A M, Zhang H F et al. Intermetallics [J], 2002, 10(1-2): 1283

13 Yang X H, Liang S H, Wang X H et al. International Journal of Refractory Metals \& Hard Materials[J], 2010, 28(2): 305

14 Zhang J Y, Liu G, Lei S Y et al. Acta Materials[J], 2012, 60(20): 7195

15 Guo S Y, Han S, Mao H F et al. Journal of Power Sources[J], 2014, 245(1): 979

16 Romankov S, ShchetininI V, Park Y C et al. Materials Letters[J], 2012, 85(20): 109

17 Kim D K, Lee S H, Baek W H. Materials Science and Engineering $A[\mathrm{~J}], 1998,249(1-2): 197$

18 Meyers M A, Xu Y B, Xue Q. Acta Materials[J], 2003, 51(5):
1307

19 Meyers M A, Nesterenko V F, Lasalvia J C. Materials Science and Engineering $A[\mathrm{~J}], 2001,317(1-2): 204$

20 Murr L E, Meyers M A, Niou C S et al. Acta Materials[J], 1997, 45(1): 157

21 Pappu S, Kennedy C, Murr L E et al. Scripta Materialia[J], 1996, 35(8): 959

$22 \mathrm{Wu}$ J, Liu J B, Du Y X. International Journal of Impact Engineering[J], 2007, 34(7): 1147

23 Schneider M S, Kad. B, Kalantar D H et al. International Journal of Impact Engineering [J], 2005, 32(1-4): 473

24 Zhang Y, Tao N R, Lu K. Scripta Materialia[J], 2009, 60(4): 211

\title{
铇丝增强铜基复合材料超高速撞击后的微观损伤
}

\author{
张 杨，吴 哲 \\ (东北林业大学, 黑龙江 哈尔滨 150040)
}

\begin{abstract}
摘 要: 通过渗流铸造的方法将 $\mathrm{Cu}_{78} \mathrm{Al}_{10} \mathrm{Fe}_{6} \mathrm{Ni}_{6}$ 合金与铇丝复合制备出 $\mathrm{Wf} / \mathrm{Cu}_{78} \mathrm{Al}_{10} \mathrm{Fe}_{6} \mathrm{Ni}_{6}$ 复合材料。采用二级轻气炮进行 $\mathrm{Wf} / \mathrm{Cu}_{78} \mathrm{Al}_{10} \mathrm{Fe}_{6} \mathrm{Ni}_{6}$ 复合材料弹体超高速侵彻混凝土靶的实验, 实验速度为 $2.4 \mathrm{~km} / \mathrm{s}$ 。借助透射电镜对侵彻后剩余弹体的微观组织进行观察, 由于侵彻过程 中高温高压的作用, 剩余弹体的不同区域出现了不同的微观组织, 从弹头到弹尾依次出现了非晶组织、再结晶、孪晶、层错和位错。非 晶组织是由于弹体在撞击过程中产生的高温使基体铜合金发生了熔化而后又快速凝固产生的, 再结晶组织是由于基体铜发生了旋转动态 再结晶而产生的, 孪晶、层错、高密度位错是由于弹体在侵彻过程中受到大的动载荷冲击发生严重塑性变形而产生的。
\end{abstract}

关键词: 复合材料; 微观组织; 高速冲击

作者简介: 张 杨, 男, 1981 年生, 博士, 讲师, 东北林业大学机电工程学院, 黑龙江 哈尔滨 150040, 电话: 0451-82190397, E-mail: 13136661358@163.com 